\title{
OPTIMASI GELLING AGENT DAN HUMEKTAN GEL HANDSANITIZER MINYAK ATSIRI DAUN JERUK LIMAU (Citrus amblycarpa (Hassk.) Ochse.)
}

\author{
(OPTIMIZATION OF GELLING AGENT AND HUMECTANT HANDSANITIZER GEL OF LIME \\ LEAF ESSENTIAL OIL (Citrus amblycarpa (Hassk.) Ochse.))
}

\author{
I GEDE MADE SURADNYANA ${ }^{\bullet}$, I KADEK WIRATA $^{1}$, NI MADE DHARMA SHANTINI SUENA ${ }^{1}$ \\ ${ }^{1}$ Fakultas Farmasi Universitas Mahasaraswati Denpasar
}

\begin{abstract}
Abstrak: Pemakaian alkohol dalam sediaan handsanitizer dapat menyebabkan kulit kering dan iritasi. Minyak atsiri daun jeruk limau memiliki aktivitas sebagai antimikroba sehingga dapat digunakan alternatif bahan aktif gel handsanitizer. Gelling agent dan humektan merupakan komponen utama sediaan gel. Gelling agent dan humektan yang banyak digunakan adalah CMC-Na dan gliserin. Untuk mendapatkan komposisi optimal gelling agent dan humektan dalam sediaan gel perlu dilakukan optimasi. Penelitian ini bertujuan untuk mendapatkan komposisi gelling agent $\mathrm{CMC}-\mathrm{Na}$ dan humektan gliserin yang optimal pada sediaan gel handsanitizer minyak atsiri daun jeruk limau. Penelitian ini merupakan eksperimental laboratorium dengan metode desain faktorial yang menggunakan dua faktor yaitu CMC-Na dan gliserin dengan dua level yaitu level tinggi dan rendah. Respon yang diamati adalah sifat fisik sediaan yang meliputi daya sebar dan daya lekat sediaan dengan analisis data menggunakan perangkat lunak Design Expert dan SPSS. Hasil dari penelitian ini menunjukkan bahwa CMC-Na dan gliserin memberikan respon yang signifikan terhadap penurunan daya sebar dan peningkatan daya lekat, serta CMC-Na sebagai faktor yang dominan. Area formula optimal dari kombinasi CMC-Na dan gliserin telah diperoleh dengan persamaan daya sebar $\mathrm{Y}=12.29167-5.74000\left(\mathrm{X}_{1}\right)-$ $0.1820009\left(\mathrm{X}_{2}\right)+0.138667\left(\mathrm{X}_{1} \mathrm{X}_{2}\right)$ dan persamaan daya lekat $\mathrm{Y}=-1.76333+4.28000\left(\mathrm{X}_{1}\right)+0.360000\left(\mathrm{X}_{2}\right)-$ $0.018667\left(\mathrm{X}_{1} \mathrm{X}_{2}\right)$.
\end{abstract}

Kata Kunci: $C M C-N a$, desain faktorial, gel hand sanitizer, gliserin, minyak atsiri daun jeruk limau

Abstract: The use of alcohol in the hand sanitizer preparation can causes dry skin and irritation. Lime leaf essential oil has antimicrobial activity so that it can be used as an alternative active ingredient of gel hand sanitizer. Gelling agents and humectants are the main components of gel preparations. The most widely used gelling agents and humectants are CMC-Na and glycerin. To get the optimal composition of gelling agent and humectant in gel preparations, optimization is needed. The aim of this study was to obtain the optimal CMC-Na gelling agent composition and glycerin humectant on the hand sanitizer gel preparation of lime leaf essential oil.

This research is an experimental laboratory with a factorial design method that uses two factors, CMC-Na and glycerin with two levels, high and low levels. The observed response was the physical properties of the preparations which included spread ability and adhesion strength of the preparations with data analysis using Design Expert software and SPSS.

The results of this study indicate that $\mathrm{CMC}-\mathrm{Na}$ and glycerin provide a significant response to the decrease in spread ability and increase in adhesion, and CMC-Na as a dominant factor. The optimal formula area from the combination of CMC-Na and glycerin has been obtained with the spread ability equation $\mathrm{Y}=12.29167-5.74000(\mathrm{X} 1)-0.1820009(\mathrm{X} 2)+0.138667(\mathrm{X} 1 \mathrm{X} 2)$ and the adhesive power equation $\mathrm{Y}=-1.76333+4.28000(\mathrm{X} 1)+0.360000(\mathrm{X} 2)+0.138667(\mathrm{X} 1 \mathrm{X} 2)$ and the sticky power equation $\mathrm{Y}=-1.76333+4.28000(\mathrm{X} 1)+0.360000(\mathrm{X} 2) \mathrm{X} 2)-0.018667(\mathrm{X} 1 \mathrm{X} 2)$.

Keywords: CMC-Na, factorial design, hand sanitizer gel, glycerin, lime leaf essential oil

\section{PENDAHULUAN}

Kebersihan tangan merupakan salah satu faktor yang harus diperhatikan dalam upaya pemeliharaan kesehatan, karena tangan merupakan jalan masuk kuman yang paling umum. Gel handsanitizer merupakan salah satu produk yang dapat digunakan untuk membersihkan tangan secara praktis tanpa harus melalui proses pembilasan.

Etanol dengan kadar 60-85\% merupakan bahan aktif yang sering digunakan dalam produk handsanitizer karena mampu membunuh bakteri,

•email korespondensi: gedesurad@gmail.com 
jamur atau virus yang terdapat pada tangan (Mithun, 2015). Penggunaan etanol sebagai pembersih tangan memiliki kelemahan karena dapat melarutkan lemak pada kulit yang berfungsi sebagai pelindung kulit sehingga pemakaian berulang dapat menyebabkan kulit kering dan iritasi (Bessonneau dkk., 2010).

Minyak atsiri adalah senyawa metabolit sekunder yang telah dikenal memiliki aktivitas sebagai antibakteri. Aktivitas antibakteri minyak atsiri disebabkan karena minyak atsiri mengandung senyawa yang dapat menghambat pertumbuhan atau membunuh bakteri. Komponen minyak atsiri yang mengandung gugus fenol seperti carvacrol berpotensi sebagai antibakteri (Yuksel dkk., 2006). Geraniol, menthol, terpinen-4-ol, linalol, kamfor, 1,8-sineol, menthon, D-limonen dan $\alpha$-pinen memiliki aktivitas antibakteri terhadap Streptococcus pneumonia, Stapilococcus aureus dan Escherichia coli (Inouye dkk., 2001). Minyak atsiri dari daun jeruk limau mengandung $\beta$-pinena, linalool, sitronelal, sitronelol dan geraniol. Rendemen minyak atsiri daun jeruk limau sebesar 0,47\% mampu menghambat pertumbuhan bakteri $S$. aureus dengan nilai KBM dan KHM sebesar 0,039\% (v/v) (Mulyani, 2009).

Berdasarkan data tersebut maka minyak atsiri dari daun jeruk limau dapat dijadikan alternatif untuk menggantikan etanol sebagai bahan aktif gel handsanitizer. Gelling agent dan humektan merupakan komponen utama sediaan gel. Gelling agent yang banyak digunakan adalah CMC-Na dan humektan yang banyak digunakan adalah gliserin. Untuk mendapatkan komposisi optimal gelling agent dan humektan dalam sediaan gel perlu dilakukan optimasi. Salah satu metode optimasi untuk proporsi masing-masing komponen yang tidak sama adalah design factorial.

\section{METODE PENELITIAN}

Rancangan penelitian. Penelitian ini merupakan penelitian eksperimental laboratorium menggunakan desain faktorial yang bersifat eksploratif, yaitu mencari area komposisi gliserin sebagai humektan dan CMC-Na sebagai gelling agent gel handsanitizer minyak atsiri daun jeruk limau yang memiliki sifat fisik (homogenitas, daya sebar, daya lekat, dan $\mathrm{pH}$ ) yang optimal.

Penelitian dilakukan di Laboratorium Fakultas Farmasi Universitas Mahasaraswati Denpasar pada bulan November 2018 sampai dengan Juni 2019.

Bahan. Bahan yang digunakan adalah daun jeruk limau (Citrus amblycarpa (Hassk.) Ochse.) yang diperoleh di kelurahan Sumerta Kelod, kecamatan Denpasar Timur, produk gel handsanitizer yang beredar di pasaram, CMC-Na, gliserin, metilparaben, propilparaben, dan aquadest.

Alat. Alat yang digunakan adalah: mortir, stemper, gelas ukur, timbangan analitik, cawan porselen, corong pisah, gelas arloji, batang pengaduk, kertas perkamen, kertas saring, aluminium foil, pipet tetes, kaca objek, sudip, sendok tanduk, wadah gel, $\mathrm{pH}$ indikator universal, kaca ekstensometer, gelas objek, erlenmeyer, anak timbangan, stopwatch, mixer Miyako $^{\circledR}$, destilator uap dan perangkat lunak Design Expert versi 11.0.5.0.

Prosedur:

Destilasi daun jeruk limau. Daun jeruk limau segar ditimbang, dimasukkan ke dalam labu destilasi. Alirkan uap air ke dalam sistem destilasi, lakukan destilasi \pm 4 jam. Destilat yang diperoleh terdiri dari dua lapisan (lapisan air dan lapisan minyak). Pisahkan lapisan minyak atsiri dengan menggunakan corong pisah.

Penetapan rentang sifat fisik gel handsanitizer yang beredar di pasaran. Disiapkan enam produk gel handsanitizer yang beredar dipasaran, kemudian keenam produk diuji mutu fisiknya berupa daya sebar dan daya lekat. Didapatkan rentang batas atas dan batas bawah dari respon daya sebar dan daya lekat yang diuji.

\section{Orientasi penentuan level rendah dan level tinggi} CMC-Na dan gliserin. Dibuat beberapa formula dengan konsentrasi CMC-Na yang bervariasi dengan konsentrasi gliserin tetap. Perlakuan yang sama dibuat formula dengan konsentrasi gliserin yang bervariasi dengan konsentrasi CMC-Na yang tetap. Dibuat gel handsanitizer sesuai dengan masihmasing formula yang telah dibuat, diuji sifat fisik sediaan setelah 48 jam pembuatan meliputi daya sebar dan daya lekat. Hasil uji dibandingkan dengan rentang produk pasaran yang telah ditetapkan. Didapatkan level rendah dan level tinggi dari CMCNa dan Gliserin.

Pembuatan gel. Propilparaben dilarutkan dengan 10 $\mathrm{ml}$ air dalam beaker glass kemudian diaduk hingga larut di atas penangas air. Metilparaben dilarutkan dengan $10 \mathrm{ml}$ air dalam beaker glass berbeda kemudian diaduk hingga larut di atas penangas air. CMC-Na dikembangkan dalam air panas hasil pelarutan propil dan metilparaben gerus dengan kecepatan konstan, kemudian ditambahkan $10 \mathrm{ml}$ air digerus kembali. Campuran yang diperoleh ditambahkan gliserin secara perlahan sambil digerus sampai homogen. Ditambahkan 0,2 gram minyak atsiri digerus kembali. Pada campuran ditambahkan sisa akuades dan digerus selama tiga menit dengan kecepatan konstan. Lama pengadukan satu formula adalah tiga menit. Cara yang sama juga dilakukan 
untuk formula lainnya dengan jumlah CMC-Na dan gliserin yang bervariasi, namun jumlah minyak atsiri dan eksipien lainnya tetap.

Tabel 1 Formula Gel Handsanitizer

\begin{tabular}{ccccc}
\hline \multirow{2}{*}{ Bahan } & \multicolumn{4}{c}{ Formula (gram) } \\
\cline { 2 - 5 } & $\mathbf{1}$ & $\mathbf{A}$ & $\mathbf{B}$ & $\mathbf{A B}$ \\
\hline Minyak atsiri daun & 0,2 & 0,2 & 0,2 & 0,2 \\
jeruk limau & 0,75 & 1,25 & 0,75 & 1,25 \\
CMC-Na & 5 & 5 & 10 & 10 \\
Gliserin & 0,09 & 0,09 & 0,09 & 0,09 \\
Metilparaben & 0,01 & 0,01 & 0,01 & 0,01 \\
Propilparaben & $\mathbf{5 0}$ & 50 & 50 & 50 \\
Aquadest ad. & & & &
\end{tabular}

Keterangan:

1 : formula dengan komposisi faktor A (CMC-Na) dan faktor B (gliserin) pada level rendah

A : formula dengan komposisi faktor A (CMC-Na) pada level tinggi sedangkan faktor B (gliserin) pada level rendah

B : formula dengan komposisi faktor A (CMC-Na) pada level rendah sedangkan faktor B (gliserin) pada level tinggi

$\mathrm{AB}$ : formula dengan komposisi faktor A (CMC-Na) dan faktor B (gliserin) pada level tinggi

Uji sifat fisik sediaan. Pemeriksaan organoleptik meliputi pemeriksaan konsistensi, warna dan bau. Pengujian homogenitas dilakukan dengan cara sampel gel dioleskan pada keping kaca, sediaan harus menunjukkan susunan yang homogen dan tidak terlihat adanya butir-butir yang kasar (Lucyani dkk., 2014). Penentuan $\mathrm{pH}$ dilakukan terhadap sediaan yang sudah diencerkan menggunakan indikator universal. Pengujian daya sebar dilakukan dengan cara sebanyak 0,5 gram gel diletakan di tengah alat ekstensometer, kemudian ditutup dengan kaca penutup dan dibiarkan salama 1 menit, dicatat diameternya. Setelah itu, ditambahkan 150 gram beban didiamkan selama 1 menit dan diukur diameter akhir (Anis, 2016). Pengujian daya lekat gel dilakukan dengan cara sebanyak 0,25 gram gel dan diletakan di atas gelas objek yang telah diketahui luasnya. Diletakkan gelas objek yang lain di atas gel tersebut, ditekan dengan beban 1000 gram selama 5 menit. Ditarik gelas objek secara berlawanan dengan beban seberat 50 gram dan catat waktunya hingga kedua gelas objek terlepas (Roudhatini, 2013).

Analisis data. Data kuantitatif yang diperoleh melalui uji sifat fisik gel dianalisis menggunakan perangkat lunak Design Expert versi 11.0.5.0. Berdasarkan analisis statistik tersebut dapat diketahui efek dari CMC-Na, efek gliserin, dan interaksinya, serta faktor mana yang lebih berpengaruh terhadap respon sifat fisik daya sebar sediaan. Dari analisis tersebut dapat diperoleh koefisien untuk melengkapi persamaan $\mathrm{Y}=\mathrm{b}_{0}+\mathrm{b}_{1} \mathrm{X}_{1}+\mathrm{b}_{2} \mathrm{X}_{2}+\mathrm{b}_{12} \mathrm{X}_{1} \mathrm{X}_{2}$. Dari persamaan ini kemudian digunakan untuk membuat contour plot sifat fisik gel handsanitizer minyak atsiri daun jeruk limau. Masing-masing contour plot digabungkan menjadi contour plot superimposed untuk mengetahui area komposisi optimum CMC-Na dan gliserin.

Validasi area komposisi optimum dilakukan dengan cara mengambil titik cuplikan secara acak pada area yang diarsir, kemudian dibuat kembali sediaan gel handsanitizer minyak atsiri daun jeruk limau. Sediaan gel yang dibuat kemudian diuji respon sifat fisik berupa daya sebar dan daya lekat.

\section{HASIL DAN PEMBAHASAN}

Hasil uji sifat fisik sediaan handsanitizer yang beredar di pasaran menunjukkan daya sebar bervariasi dari 5,0-8,2 $\mathrm{cm}$ dan daya lekat bervariasi dari 3,06-7,50 detik.

Tabel 2 Hasil Uji Daya Sebar dan Daya Lekat Produk Handsanitizer di Pasaran

\begin{tabular}{ccc}
\hline Produk & Daya Sebar $(\mathbf{c m})$ & $\begin{array}{c}\text { Daya Lekat } \\
(\text { detik })\end{array}$ \\
\hline $\mathbf{A}$ & 6,8 & 6,41 \\
B & 5,0 & 7,28 \\
C & 6,5 & 7,50 \\
D & 6,1 & 4,26 \\
E & 8,2 & 3,06 \\
F & 5,2 & 3,76 \\
\hline
\end{tabular}

Uji sifat fisik terhadap produk sejenis yang beredar di pasaran bertujuan untuk mendapatkan gambaran rentang daya sebar dan daya lekat yang optimal untuk produk handsanitizer, mengingat tidak ada standar sifat fisik yang disyaratkan di pustaka.

Hasil uji sifat fisik sediaan dengan kadar CMC$\mathrm{Na}$ bervariasi tetapi kadar gliserin konstan (15\%) menunjukkan bahwa semakin tinggi kadar CMC-Na daya sebar sediaan semakin rendah dan daya lekatnya semakin tinggi. Sediaan gel yang memiliki daya sebar yang memenuhi rentang standar $(5,0-8,2 \mathrm{~cm})$ adalah gel degan kadar CMC-Na 1,5-2,5\%, sedangkan sediaan yang memiliki daya lekat memenuhi standar (3,06-7,50 detik) adalah sediaan dengan kadar CMC$\mathrm{Na} 1-2,5 \%$. Dengan demikian maka level rendah CMC-Na adalah 1,5\% dan level tingginya 2,5\%.

Hasil uji sifat fisik sediaan dengan kadar CMC$\mathrm{Na}$ konstan (2\%) tetapi kadar gliserin bervariasi (5$30 \%$ ) menunjukkan bahwa semakin tinggi kadar gliserin daya sebar sediaan semakin rendah dan daya lekatnya semakin tinggi. Sediaan gel yang memiliki daya sebar yang memenuhi rentang standar $(5,0-8,2$ $\mathrm{cm})$ adalah gel degan kadar gliserin $5-20 \%$, sedangkan sediaan yang memiliki daya lekat memenuhi standar (3,06-7,50 detik) adalah sediaan 
dengan kadar gliserin 10-20\%. Dengan demikian maka level rendah gliserin adalah $10 \%$ dan level tingginya $20 \%$.

Tabel 3 Hasil Uji Respon Sifat Fisik Sediaan Gel dengan Variasi Kadar CMC-Na

\begin{tabular}{ccc}
\hline $\begin{array}{c}\text { CMC-Na } \\
(\%)\end{array}$ & Daya sebar $(\mathbf{c m})$ & $\begin{array}{c}\text { Daya lekat } \\
\text { (detik) }\end{array}$ \\
\hline 1 & 10,48 & 2,53 \\
1,5 & 6,97 & 5,68 \\
2 & 5,93 & 589 \\
2,5 & 5,04 & 6,74 \\
3 & 4,38 & 15,05 \\
\hline
\end{tabular}

Tabel 4 Hasil Uji Respon Sifat Fisik Sediaan Gel dengan Variasi Kadar Gliserin

\begin{tabular}{ccc}
\hline Gliserin (\%) & Daya sebar (cm) & $\begin{array}{c}\text { Daya lekat } \\
\text { (detik) }\end{array}$ \\
\hline 5 & 6 & 2,40 \\
10 & 5,91 & 3,97 \\
15 & 5,57 & 6,09 \\
20 & 5,54 & 6,97 \\
25 & 1,51 & 11,35 \\
30 & 1,35 & 23,83 \\
\hline
\end{tabular}

Hasil pengujian sifat fisik sediaan gel handsanitizer minyak atsiri daun jeruk limau disajikan pada Tabel 5. Uji organoleptis dilakukan dengan cara mengamati konsistensi, warna, dan bau dari sediaan gel yang telah dibuat. Hasil dari uji setelah penyimpanan 48 jam menunjukkan gel opak, berwujud semi solid serta bau daun jeruk limau yang khas. Semua formula menunjukkan sifat organoleptis yang sama. Pada saat diaplikasikan ke permukaan telapak tangan, sediaan nyaman ketika digunakan. Hasil dari uji homogenitas setelah penyimpanan 48 jam menunjukkan tidak terdapat partikel atau gumpalan yang terbentuk pada semua formula sehingga dapat disimpulkan bahwa sediaan homogen. Sediaan yang homogen akan memberikan hasil yang baik, karena bahan aktif dapat terdispersi merata dalam bahan pembawanya, sehingga dalam setiap bagian gel memiliki bahan aktif dalam jumlah yang sama (Meliani, 2015).

Uji daya sebar bertujuan untuk mengetahui kemampuan sediaan menyebar pada kulit pada saat digunakan. Suatu sediaan gel harus memiliki daya sebar yang baik ditandai dengan tingginya daerah penyebarannya agar zat aktif yang terkandung di dalam sediaan gel dapat tersebar secara merata dan gel dapat bekerja secara efektif (Priawanto dan Hadning, 2017). Kriteria daya sebar yang telah ditentukan berdasarkan uji daya sebar terhadap kontrol adalah $5,0-8,2 \mathrm{~cm}$. Hasil pengujian daya sebar sediaan gel handsanitizer menunjukkan bahwa daya sebar dari keempat formula berada dalam rentang daya sebar yang diinginkan. Nilai daya sebar berbanding terbalik dengan nilai viskositas, sehingga apabila sediaan gel memiliki nilai viskositas yang tinggi maka nilai daya sebarnya akan semakin rendah (Garg dkk., 2002).

Tabel 5 Hasil Uji Sifat Fisik 48 Jam Setelah Pembuatan

\begin{tabular}{|c|c|c|c|c|c|c|c|}
\hline & 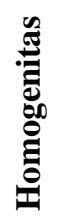 & 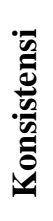 & 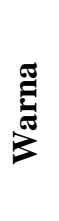 & $\underset{\tilde{\Theta}}{\vec{\Xi}}$ & $\frac{\pi}{2}$ & 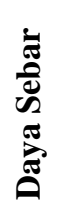 & 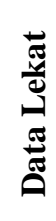 \\
\hline 1 & 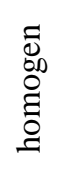 & 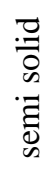 & 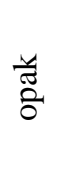 & 旁 & $r$ & $\begin{array}{l}0 \\
1 \\
0 \\
+1 \\
+1 \\
8 \\
0 \\
-\end{array}$ & $\begin{array}{l}0 \\
0 \\
0 \\
+1 \\
\infty \\
\infty \\
\dot{\infty}\end{array}$ \\
\hline $\mathbf{A}$ & 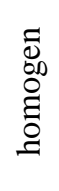 & 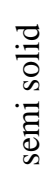 & 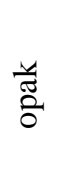 & 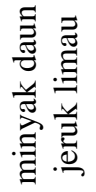 & $r$ & $\begin{array}{l}8 \\
0 \\
+1 \\
5 \\
0 \\
i\end{array}$ & 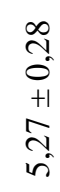 \\
\hline B & 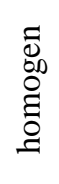 & 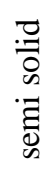 & 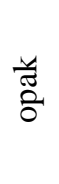 & 旁 & $r$ & $\begin{array}{l}\exists \\
0 \\
+1 \\
\vec{n} \\
-1\end{array}$ & $\begin{array}{l}\tilde{2} \\
\tilde{\sigma} \\
+1 \\
\dot{\sigma} \\
\dot{\sigma}\end{array}$ \\
\hline AB & 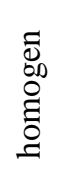 & 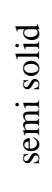 & 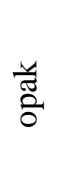 & 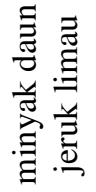 & $r$ & $\begin{array}{l}8 \\
0 \\
0 \\
+1 \\
0 \\
0 \\
i\end{array}$ & $\begin{array}{l}n \\
0 \\
0 \\
+1 \\
2 \\
o \\
0\end{array}$ \\
\hline
\end{tabular}

Uji daya lekat bertujuan untuk mengetahui kemampuan gel menempel pada permukaan kulit. Semakin melekat gel pada kulit maka zat aktif yang berdifusi pada kulit semakin banyak sehingga gel yang digunakan semakin efektif (Voigt, 1984). Kriteria daya lekat yang telah ditentukan berdasarkan uji daya lekat terhadap kontrol adalah 3,06-7,50 detik. Hasil pengujian daya lekat sediaan gel handsanitizer menunjukkan bahwa daya lekat dari keempat formula berada dalam rentang daya lekat yang diinginkan. Nilai daya lekat dipengaruhi viskositas gel. Apabila viskositas tinggi, maka nilai daya lekat juga semakin tinggi (Priawanto dan Hadning, 2017).

Tabel 6 Nilai Efek CMC-Na dan Gliserin serta Interaksi terhadap Respon Daya Sebar Gel Handsanitizer Minyak Atsiri Daun Jeruk Limau

\begin{tabular}{cccc}
\hline Faktor & Efek & p-value & $\begin{array}{c}\text { Kontribusi } \\
(\boldsymbol{\%})\end{array}$ \\
\hline CMC-Na & $-2,35$ & $<0,0001$ & 97,60 \\
Gliserin & $-0,22$ & 0,0361 & 0,83 \\
CMC-Na - & 0,17 & 0,0791 & 0,54 \\
Gliserin & & & \\
\hline
\end{tabular}


Berdasarkan Tabel 6 efek dari CMC-Na dan gliserin bernilai negatif yang menunjukkan bahwa CMC-Na dan gliserin memiliki efek menurunkan daya sebar secara signifikan menurunkan daya sebar ( $p$-value <0,05). Efek interaksi CMC-Na dengan gliserin bernilai positif yang menunjukkan bahwa interaksi keduanya memiliki efek meningkatkan daya sebar dan tidak memberikan efek yang signifikan dengan $p$-value $>0,05$. CMC-Na dengan kontribusi sebesar 97,60\% memberikan efek yang paling dominan dalam menurunkan respon daya sebar. Gambar 1 menunjukkan peningkatan kadar gliserin dapat menurunkan daya sebar gel handsanitizer pada CMC-Na level rendah ataupun pada CMC-Na level tinggi. Garis berwarna hitam menunjukkan CMC-Na level rendah dan garis berwarna merah menunjukkan CMC-Na level tinggi.

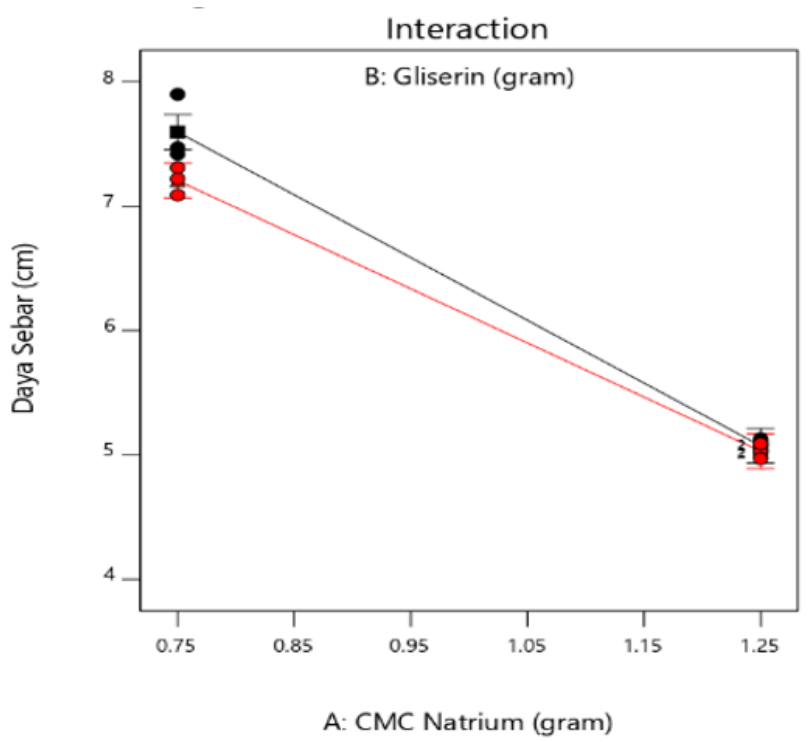

Gambar 1 Hasil Model Grafik Efek CMC-Na terhadap Respon Daya Sebar Gel Handsanitizer Minyak Atsiri Daun Jeruk Limau

Tabel 7 Nilai efek CMC-Na dan Gliserin serta Interaksi terhadap Respon Daya Lekat Gel Handsanitizer Minyak Atsiri Daun Jeruk Limau

\begin{tabular}{cccc}
\hline Faktor & Efek & p-value & $\begin{array}{c}\text { Kontribusi } \\
(\%)\end{array}$ \\
\hline CMC-Na & 2,07 & $<0,0001$ & 58,23 \\
Gliserin & 1,71 & $<0,0001$ & 39,60 \\
CMC-Na - & $-0,02$ & 0,8730 & 0,01 \\
Gliserin & & \\
\hline
\end{tabular}

Berdasarkan Tabel 7 efek CMC-Na dan gliserin bernilai positif yang menunjukkan bahwa CMC-Na dan gliserin memiliki efek meningkatkan daya lekat secara signifikan dengan $p$-value $<0,05$. Efek dari interaksi antara CMC-Na dengan gliserin bernilai negatif yang menunjukkan bahwa interaksi CMC-Na dengan gliserin memiliki efek menurunkan daya lekat dan tidak memberikan efek yang signifikan dengan $p$-value $>0,05$. CMC-Na dengan kontribusi sebesar 58,23\% memberikan efek yang paling dominan dalam meningkatkan respon daya lekat.

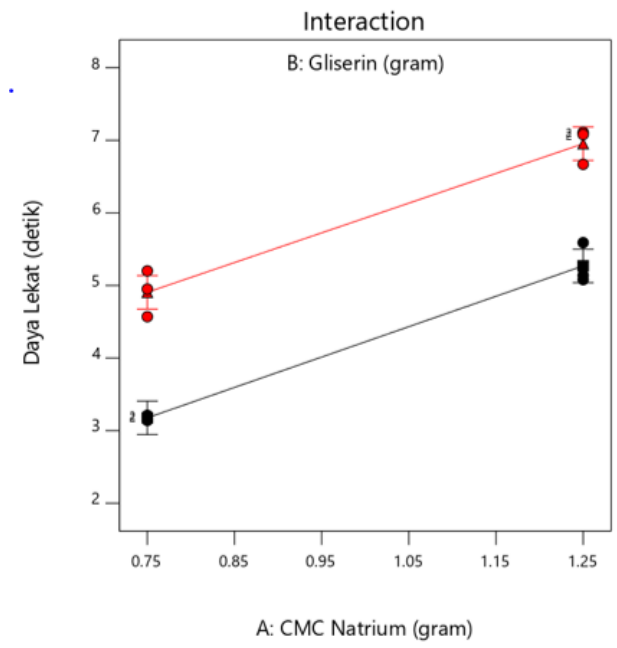

Gambar 2 Hasil Model Grafik Efek CMC-Na terhadap Respon Daya Lekat Gel Handsanitizer Minyak Atsiri Daun Jeruk Limau

Gambar 2 menunjukkan peningkatan dari CMC-Na dapat menaikkan daya lekat gel handsanitizer pada gliserin level rendah maupun tinggi. Garis berwarna hitam menunjukkan gliserin level rendah dari faktor dan garis berwarna merah menunjukkan gliserin level tinggi.

Gambar 3 Hasil Model Grafik Efek Gliserin terhadap Respon Daya Lekat Gel Handsanitizer Minyak Atsiri Daun Jeruk Limau

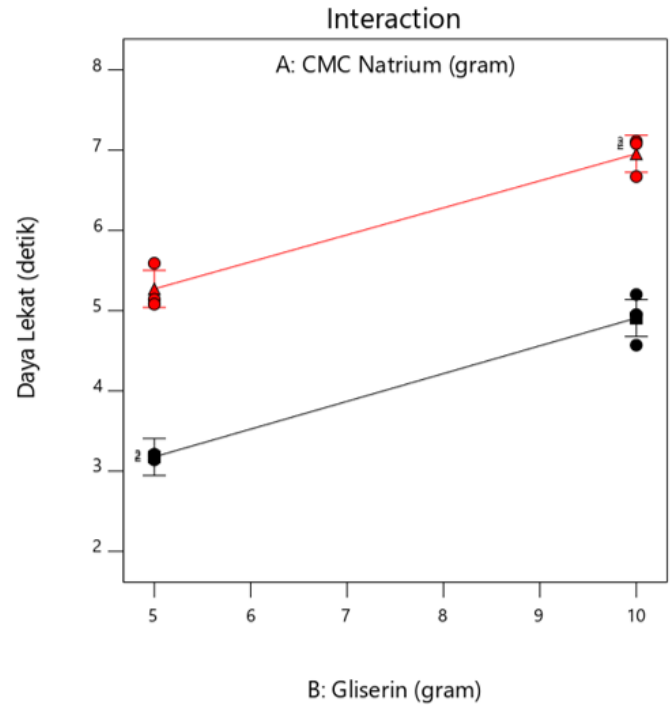

Gambar 3 menunjukkan peningkatan gliserin dapat menaikkan daya lekat gel handsanitizer pada CMC-Na level rendah maupun level tinggi. Garis berwarna hitam menunjukkan CMC-Na level rendah dan garis berwarna merah menunjukkan CMC-Na level tinggi. 
Optimasi formula bertujuan untuk mencari komposisi optimum dari faktor yang diteliti, yaitu CMC-Na dan gliserin agar menghasilkan gel handsanitizer yang memenuhi kriteria sifat fisik yang diinginkan. Untuk mendapatkan area optimum, maka setiap pengujian sifat fisik (daya sebar dan daya lekat) gel handsanitizer minyak atsiri daun jeruk limau dibuat ke dalam grafik contour plot dan dipilih area yang memenuhi persyaratan sifat fisik gel yang diinginkan. Area tersebut kemudian digabungkan dalam contour plot superimposed. Contour plot superimposed merupakan area optimum yang didapatkan berdasarkan data respon sifat fisik yaitu daya sebar dan daya lekat yang dihasilkan pada keempat formula dalam penelitian ini yaitu formula 1, A, B, dan AB.

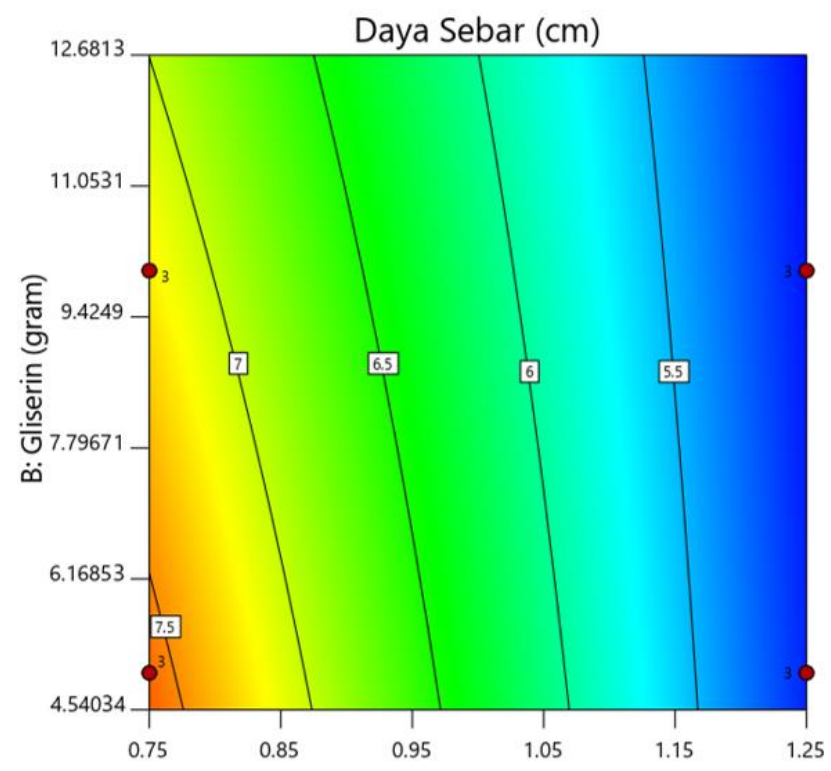

A: CMC Natrium (gram)

Gambar 4 Contour Plot Respon Daya Sebar Sediaan Gel Handsanitizer Minyak Atsiri Daun Jeruk Limau

Contour plot daya sebar menunjukkan semakin banyak penggunaan $\mathrm{CMC}-\mathrm{Na}$ atau gliserin dapat menurunkan nilai daya sebar dari sediaan. Daerah berwarna merah ke daerah berwarna biru menunjukkan daerah dengan daya sebar yang tinggi ke daerah dengan daya sebar yang rendah. Contour plot daya sebar didapatkan dari rentang daya sebar yang diinginkan yaitu 5,0-8,2 cm. Respon daya sebar berdasarkan uji ANOVA pada taraf kepercayaan 95\% didapatkan persamaan desain faktorial terhadap daya sebar $\quad \mathrm{Y}=12.29167-5.74000\left(\mathrm{X}_{1}\right)-0.1820000\left(\mathrm{X}_{2}\right)+$ $0.138667\left(\mathrm{X}_{1} \mathrm{X}_{2}\right)$, dengan $\mathrm{Y}$ adalah daya sebar, $\mathrm{X}_{1}$ adalah CMC-Na, $X_{2}$ adalah gliserin dan $X_{1} X_{2}$ merupakan interaksi antara CMC-Na dan gliserin. Persamaan signifikan karena memiliki $p$-value $<0,05$ sehingga dapat digunakan optimasi.

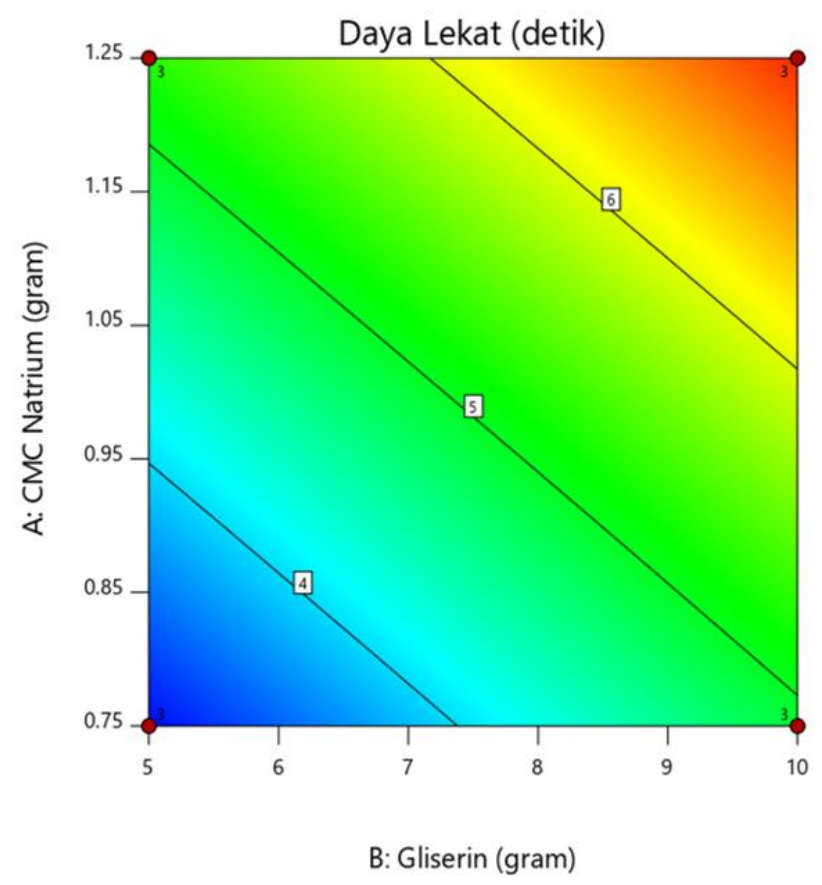

Gambar 5 Contour Plot Respon Daya Lekat Sediaan Gel Handsanitizer Minyak Atsiri Daun Jeruk Limau

Contour plot daya lekat menunjukkan semakin banyak penggunaan CMC-Na atau gliserin dapat meningkatkan nilai daya lekat dari sediaan. Daerah berwarna biru ke daerah berwarna merah menunjukkan daerah dengan daya lekat yang rendah ke daerah dengan daya lekat yang tinggi. Contour plot daya lekat didapatkan dari rentang daya lekat yang diinginkan yaitu 3,06-7,50 detik. respon daya lekat berdasarkan uji ANOVA pada taraf kepercayaan 95\% didapatkan persamaan $\mathrm{Y}=-1.76333+4.28000\left(\mathrm{X}_{1}\right)+$ $0.360000\left(\mathrm{X}_{2}\right)-0.018667\left(\mathrm{X}_{1} \mathrm{X}_{2}\right)$, dengan $\mathrm{Y}$ adalah daya lekat, $X_{1}$ adalah CMC-Na, $X_{2}$ adalah gliserin dan $\mathrm{X}_{1} \mathrm{X}_{2}$ merupakan interaksi antara CMC-Na dan gliserin. Persamaan signifikan karena memiliki $p$ value $<0,05$ sehingga dapat digunakan optimasi.

Contour plot superimposed menggambarkan formula yang memiliki sifat fisik optimum. Daerah berwarna kuning menunjukkan kombinasi faktor yang akan diteliti. X1 adalah faktor CMC-Na dan X2 adalah faktor gliserin. Contour plot superimposed yang didapatkan ditunjukkan pada Gambar 6. Area arsiran berwarna kuning merupakan area komposisi optimum untuk mendapatkan sediaan gel handsanitizer minyak atsiri daun jeruk limau dengan sifat fisik yang dikehendaki, yaitu daya sebar sebesar 5,0-8,2 cm dan daya lekat sebesar 3,06-7,50 detik.

Validasi terhadap area optimum yang diperoleh bertujuan untuk mengetahui kesesuaian dari hasil validasi dengan hasil teoritis yang didapatkan dari persamaan contour plot superimposed dan untuk memastikan bahwa persamaan yang didapatkan valid. Validasi dilakukan 
dengan mengambil salah satu titik secara acak pada 100 prediksi yang terdapat pada area optimum. Titik yang diambil memiliki komposisi CMC-Na sebesar $2 \%$ (1 gram) dan gliserin sebesar $14 \%$ (7 gram). Hasil validasi dilihat pada Tabel 8 dimana nilai daya sebar dan daya lekat hasil validasi masuk dalam rentang yang diinginkan. Perbedaan antara daya sebar dan daya lekat secara teoritis dan hasil validasi dianalisis menggunakan uji t-test unpaired untuk mengetahui signifikansi perbedaan dua data antara data teoritis dengan data hasil validasi berasal dari satu populasi yang sama. Hasil dari uji t-test adalah berbeda tidak signifikan dengan $p$-value $>0,05$ sehingga dapat disimpulkan bahwa model persamaan desain faktorial terhadap daya sebar dan daya lekat yang didapat valid.

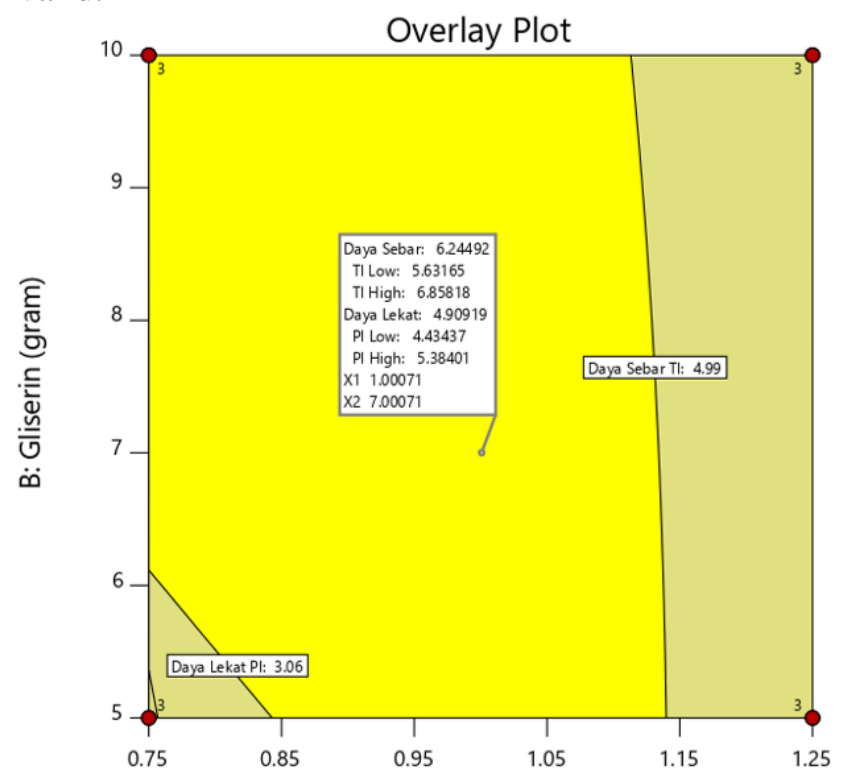

A: CMC Natrium (gram)

Gambar 6 Contour Plot Superimposed Sediaan Gel Handsanitizer Minyak Atsiri Daun Jeruk Limau

Tabel 8 Hasil Uji Validasi Contour Plot Superimposed Sediaan Gel Handsanitizer Minyak Atsiri Daun Jeruk Limau

\begin{tabular}{cccc}
\hline Respon & Teoritis & Hasil Validasi & $\begin{array}{c}p- \\
\text { value }\end{array}$ \\
\hline $\begin{array}{c}\text { Daya sebar } \\
\text { (cm) }\end{array}$ & 6,2500 & $\begin{array}{c}6,0333 \pm \\
0,14434\end{array}$ & 0,122 \\
$\begin{array}{c}\text { Daya lekat } \\
\text { (detik) }\end{array}$ & 4,9100 & $\begin{array}{c}5,0967 \pm \\
0,81464\end{array}$ & 0,730 \\
\hline
\end{tabular}

\section{SIMPULAN}

Diperoleh area komposisi formula optimum dari sediaan gel handsanitizer minyak atsiri daun jeruk limau dengan persamaan daya sebar
$\mathrm{Y}=12.29167-5.74000\left(\mathrm{X}_{1}\right)-0.1820000\left(\mathrm{X}_{2}\right)+$

$0.138667\left(\mathrm{X}_{1} \mathrm{X}_{2}\right)$ dan persamaan daya lekat $\mathrm{Y}=$

$1.76333+4.28000\left(\mathrm{X}_{1}\right)+\quad 0.360000\left(\mathrm{X}_{2}\right)-$ $0.018667\left(\mathrm{X}_{1} \mathrm{X}_{2}\right)$ serta sudah tervalidasi dengan titik validasi kombinasi CMC-Na sebesar 2\% (1 gram) dan gliserin sebesar 14\% (7 gram).

\section{UCAPAN TERIMA KASIH}

Ucapan terima kasih kami sampaikan kepada laboran Laboratorium Farmasetika dan Teknologi Farmasi atas bantuannya dalam pelaksanaan penelitian ini.

\section{DAFTAR PUSTAKA}

Anis, SAA 2016, Formulasi sediaan gel ekstrak etanol daun kirinyuh (Eupatorum odoratum L.) sebagai penyembuh luka terbuka pada kelinci, Skripsi, Surakarta, Fakultas Farmasi Universitas Muhammadiyah Surakarta.

Bessonneau, V, Clement, M, Thomas, T 2010, Can intensive use of alcohol-based hand rubs lead to passive alcoholization, Int, J, Environ, Res, Public Health, pp. 7. 3038-3050.

Garg, A, Aggarwal, D, Garg, S \& Singla, AK 2002, Spreading of semisolid formulations an update, Pharmaceutical Technology, pp. 84-105.

Inouye, S, Takizawa, T \& Yamaguchi, H 2001. Antibacterial activity of essential oil and their major constituents against respiratory by gaseous contact, Journal of Antimicrobial Chemoterapy, pp. 47. 565-573.

Lucyani, N 2014. Uji aktivitas antibakteri sediaan krim tipe M/A dari minyak atsiri kulit buah jeruk pontianak (Citrus nobilis Lour.var.microcarpa) terhadap isolat propionibacterium acnes secara invitro [skripsi], Pontianak, Fakultas Kedokteran, Universitas Tanjungpura.

Meliani, NK 2015, Formulasi dan evaluasi mutu fisik sediaan gel handsanitizer dari minyak atsiri bunga kenanga (Cananga odorata (Lam.) Hook. $f \&$ Thoms) CMC-Na sebagai gelling agent, KTI, Denpasar, Akademi Farmasi Saraswati Denpasar.

Mithun, AT, Udugade, BV, Manoj, B \& Pawade DA 2015, Formulation and evaluation of novel 
herbal hand sanitizer, Indo American Journal of Pharmaceutical Research, 5 (01), pp. 483-487.

Mulyani, S 2009, Analisis GC-MS dan daya anti bakteri minyak atsiri Citrus amblycarpa (Hassk) ochse. Fakultas Farmasi UGM.

Priawanto, PG \& Hadning, I 2017, Formulasi dan uji kualitas fisik sediaan gel getah jarak (Jatropha curcas), Karya Tulis Ilmiah, Universitas Muhammadiah Yogyakarta, Yogyakarta.

Roudhatini 2013, Uji efektivitas sediaan gel anti jerawat minyak atsiri daun jeruk sambal (Citrofortunnella microcarpa (Bunge)
Wijnands) terhadap propionibacterium acnes dan staphylococcus epidermidis, Naskah Publikasi, Pontianak, Fakultas Kedokteran Universitas Tanjung Pura Pontianak.

Voigt, R 1984, Buku pelajaran teknologi farmasi edisi 5, Gadjah Mada University Press, Yogyakarta, pp. 560-561.

Yuksel, Ucan SU, Kartal, M, Altun LM, Aslan S, Sayar E, \& Ceyhan T, 2006. GC-MS analysis and antibacterial activity of cultivated satureja cuneifolia ten essential oil. Turk J Chem, pp. 30. 253-259. 